\title{
The Impact of Christianity, Islam and Colonialism on Indigenous African Religion and Cultures
}

\author{
ALEXANDER, C. UGWUKAH, Ph.D. \\ Department of History and International Studies, Babcock University, Ilishan-Remo, Ogun State, Nigeria \\ OBINNA, I. OHAJA, M.A \\ Department of History and International Studies, Babcock University, Ilishan-Remo, Ogun State, Nigeria
}

\begin{abstract}
This paper examines the impact of foreign religions on the African Traditional Religion, their socio-political settings and culture. The work has equally endeavored to highlight the essence, content and raison d'état for the religious practices of the Africans in precolonial times. With such evaluation, the work has been able to draw out the values and functions of the religion on the socio-political and cultural settings of the African people. Adequate effort was made to review and assess the circumstances which led to the adoption and establishment of these foreign religions on Africa as a whole. For obvious reasons especially that which is related to the human rights of men in their religious views and worship, the work does not make any pretensions as to exact any effort to place the West dominated misunderstanding of the African views of religion and spirituality above other considerations. Rather, this work has embarked on the presentation of the advantages of each of these religions and more importantly, the impact it had on the African people in the past and its continued tendencies in their history. The position of the work therefore is that Africans should rather cultivate in themselves a sense of selfconfidence and assurance that the religious state of man in the African sense was the bedrock of the unique social values, morality, balance and order which regulated the society which was bereft of social ills. The work concludes that African traditional religion still remain a virtual instrument to reform our society today as it enforced obedience in the past and reverence to a supreme God as in the other religions who also is the chief moderator and administrator of the world, then, now and in the future.
\end{abstract}

Keywords: Christianity, Islam, African Traditional Religion, Culture, Colonialism.

DOI: $10.7176 / \mathrm{JPCR} / 41-04$

\section{Introduction}

Scholars in the nineteenth century, starting from the works of the father of anthropology, Edward B Taylor, created the impression that African indigenous religions was at the bottom of the religious evolution, they used such derogatory terms as fetish, idolatry, superstitious, heathenism, to describe the religious practices and ways of life of Nigerians and by extension to all Africans ${ }^{1}$ As Ajayi has rightly pointed out, "it is not therefore any gainsaying that the European Christian missionaries in Africa simply failed to appreciate the nature of the African pagan religion as something transcending mere personal beliefs and the forms of worship as a whole, social system encompassing the entire life and culture of the people, they saw in it no more than fetish idolatry and Juju". ${ }^{2}$ They simply disagreed with the tenet of the African traditional religion and their entire traditional ways of life which was in the first place rooted in paganism required to be extirpated to make way for the white man's cultural values. ${ }^{3}$ Although more recent works by modern anthropologist like E. E. Evans Pritchard, Marcel Grianle and Victor Turner as well as some African theologists like John Mbiti and Bolaji Idowu have made attempts to reverse/correct this obnoxious view, the plague has remained very difficult to erase and readdressed.

The major effect of this on Nigerians and Africans is to hold tenaciously to the view that our own indigenous religion as practiced by our fore fathers is primitive and inferior to the imported religions of Christianity, Islam, Hinduism and Buddhism. ${ }^{4}$ The overriding impression created is that the European culture is superior and both Christianity and the institution of colonialism which it paved way for has sought to suppress and degrade African cultures among other things, by making the younger generations to look down on them or abandon certain African cultural observances and practices as primitive, barbarous or unbecoming of a modern, educated person. ${ }^{5}$

The other religion relevant to this discussion which is Islam made serious impact on the cultures and ways of life and adopted a more subtle way of acculturation and therefore did not paint the exact picture of an impostor on the African religion and its way of life. Thus as Edward Blyden has rightly pointed out, the progress of Islam in its spread in Africa has been attributed in part to the fact that it did not denigrate Africans as an inferior caste nor seek to destroy their cultures. Completely as unworthy of existing alongside itself, the Africans local institutions were not destroyed by the Arab influence introduced. They only assumed new forms and adapted themselves to the new teachings. In all thriving Mohamedan communities in the west and central Africa, it may be noticed that the Arab superstructure has been super imposed on a permanent indigenous substructure so that what really took place when the Arab met the Negro in his home was healthy amalgamation and not an 
absorption or an undue repression. ${ }^{6}$ Thus, if we must accept the definition of culture as given by E.B. Taylor (1871) as "that complex whole which includes knowledge, beliefs, art, morals, customs, and other capabilities acquired by man as a member of a society," then it may not be out of place to restate that both Christianity and Islam impacted both negatively and positively on the peoples of Nigeria and other African societies.

The focus of this work is therefore to lay the cases and circumstances bare before all in other to actually assess the nature of the impact made by the two foreign religions, on the Nigerian people as well as other Africans in general. Before delving deep into this analytical presentation, it may be worth the while to expatiate on the African traditional religion and the milieu of its existence and operation before and after the coming of the other two foreign religions which affected its essence and being.

\section{Traditional Religion In Nigeria And Africa As A Whole.}

Even though the literal meaning of religion which is adopted from the Latin word, religio' reliagere translates to bind or to follow, it was not originally meant to connote following a leader or unwavering obedience or to an idea or a command. ${ }^{8}$ The original meaning was to bind the physical to the spiritual, mortality to immortality or obedience to the subjective. In the words of Plato, bind the body to the soul. In other words, religion was to be the means whereby that bond is established, the means whereby the physical naturally follows and flows into the spiritual without any break or severance. ${ }^{9}$

This statement is true of all religions but more importantly, reflects the exact milieu in which the African traditional religion operates in binding man to the supreme God. Therefore in contrast to both Christianity and Islam, it is much more difficult to discuss Africa's traditional religion. The reason for this assertion is that traditionalism does not have a sacred book as does Islam or Christianity. It has no temples of worship (except for grooves or sacrificial posts), no preachers or proselytizers, no marabouts, no religious formulas, no reformers and prophets and no missionaries. This seeming void frustrated Christian missionaries as they began their work on the continent. This problem is compounded by the fact that little is written about traditionalism (formerly labelled paganism, heathenism or even animism), because most literate Africans tend to be either Christians or Muslims or occasionally atheists and therefore are rarely interested in preserving or clarifying the African supernatural belief system.

Experts such as John Mbiti, Placid Temples, Geoffrey Parrinder and other scholars have revealed that Africa's religion is as complex as other religions of the world, in its attempt to explain human kind's existence on the planet and the issues of life and death. However Mario Azevedo has posited "it is noteworthy that a discussion of an African traditional system must have the following caveat. One is entitled to talk of African religion, only if one stresses the common elements of religious belief in Africa, if the emphasis is however on the differences (specific beliefs, rituals, responsibilities, for example), from region to region, and from ethnic group to ethnic group, then the expression African religions is more appropriate, although it renders the usage a more complicated meaning" 10 .

The term traditionalism in the context of the work refers to those supernatural beliefs and rituals which have existed on the continent since time immemorial without being substantially tampered with by foreign influences. Consequently, the word 'indigenous' describes the concept better. Thus, an attempt to capture the essence of African traditional religion reveals the following common features. First, African religion postulates the existence of one Supreme Being, God in western terminology. Each African language has its own term Ubangiji, Olodumare, Chineke, Chukwu, Osanobua etc. This God is the creator of the universe, omniscient, omnipotent and caring. Concerned in anthromorphic terms, he lives way up in the skies and therefore stands remote from his creatures. Men only approach him on special occasions directly. Otherwise, man must consult him through his intermediaries, the spirits or ancestors, sometimes inappropriately labeled by western experts as 'gods' or lesser gods, making African society polytheistic.

Mario Azevedo further highlights that in the traditional setting, true worship is only reserved to the great God because everything else is subordinate to him. The spirits are designed to protect human kind or punish evil doers and serve as intermediaries or mediators between God and man, playing a role similar to that of Christ, Angels or saints in Christianity. Ancestors are venerated and important people who lived in the community, left offspring and led an exemplary life and have joined their everlasting life and world of spirits. Ancestors are therefore the protectors of the community and guarantors of morals. In that realm, they are the living dead who can also reward or punish evil doers. Thus it must be pointed out that the eschatological (related to the end of times) concepts of final judgment, purgatory, eternity, hell and heaven found in Christianity or Islam are not part of African religious traditions. ${ }^{11}$

African Traditionalists just as Christians do offer sacrifices (portions of the new harvest for example,) pour libations to spirits and ancestors, pray for good health, rain, success and protection against the Clements. They worship at specific places such as forests, a tree, a cemetery or the back of the household on specific occasions. They also perform rituals that are specifically related to birth or death and adult-hood or marriage and use images such as sculpture, masks and other symbols with spiritual content and message on such occasions a priest, 
an elder, the chief or the head of the family may be officiating and called specialists as Mbiti has noted. ${ }^{12}$

Thus contrary to Christianity or Islamic religion, in African traditional religion, children are exposed to religion in their daily lives and not necessarily through special sermons, daily chantings or memorization (as with Islam) or through years of schooling. The constant indirect or direct briefings and admonition from parents and the clan, the songs, proverbs, riddles and rituals and taboos, all reinforce the religious message about God, the spirits or the ancestors. As a result of this patterned upbringing, children grow up into their youth with a strong sense of commitment to morals and service which permeates their entire life circle.

As Prof. Omoniyi Adewoye has rightly noted, "It is worth noting that government and politics were perceived as part of the religious process of working out the will of the ancestors and the Gods of the community." 13 The ancestors and the Gods have worked out the Charter of the community at the beginning, including the rules, and the regulations for orderly progress. Therefore in working out the will of the ancestors, every adult had a role to play as such no salaries were paid for filling a political post. Public office was a social responsibility rather than a privilege.

The communalistic concept of society or political community as averred by Adewoye was not just association of living persons to promote law and order, it was perceived primarily as a union of living blood relations, their dead and the yet unborn- a spiritual commonwealth -so to speak. All the living are seen as bound closely together by kingship ties and are linked to the dead by blood ties, which even death cannot dissolve. The hierarchy of the gods of the community were part of this spiritual commonwealth. So were the ancestors who were believed to have drawn up their charter of the community in the first instance with the approval of the gods. The Gods and the ancestors continue to have an abiding interest in the community and are believed to be constantly present and vigilant. Thus in the traditional societies in Nigeria, and Africa in general, politics and government were no more than processes of regulating normal relations as descendants of a common ancestor or founding father. ${ }^{14}$ It was only necessary that all who were old enough to talk, emphasis was placed on consensus, the general belief being that it was only through unanimity or consensus that the will of the ancestors and the gods should be ascertained. The philosophy of law as Adewoye further noted reflected the union of the community. As such a dispute between two individuals is a challenge to the elders to maintain the "cords that binds the humanity and the unbroken ties of the friendship." The primary objective in resolving any conflict was settlement, not adjudication. The elders sitting in judgement invariably had their eyes on "the future relations between the parties which are so vital to life of the community itself"15

Also, arising from the principle of political community as union is the religious and ritual character of government at the lowest level of political structure, the village. In some communities, every major decision whether of a legislative or judicial nature had to be reinforced by invoking the ancestors and the gods who were believed to be introduced in the affairs of the community. In African traditional societies, there was a deeply rooted belief in the continuity of life, a life after death and a "community of interest between the living and the dead and the generation yet unborn." There was also a general belief that God who created the community, created a set of supernatural and spiritual forces capable of intervening in life in the physical world. He therefore set up divine- beings- divinities and ancestors to police it. The belief gives rise to the idea of ethnic divinities such as Ayelaja, Jakuta and Sango among the Igbo, Sokogba among the Edo (benin), Obumo among the Ibibio, and Urhienu among the urhobo, to determine the essence of traditional religion, Geoffrey Parrinder asserts that the whole organization of traditional society was maintained by the spiritual forces which pervade it.

Other perspectives of the African system of traditions which have been seen as negative were the secret cults, sorcery, magic and animism, perpetrators of such art who were sometimes considered evil. A sorcerer usually thought to be a female is believed to travel long distances at night to cause death, illness or bad luck to enemies. Witchcraft on the other hand is an in-born (innate) uncontrollable power to cause evil in other people. Both practices or use of evil forces to manipulate the society were of course, socially unacceptable and was viewed with contempt by members of the community who countered such forces by consulting the priests, diviners or fortune tellers who could through their consultation with the spirits discover such perpetrators who in turn are dealt with according to societal norms. Magic, the ability to manipulate the powers of nature of the vital force. Magic can be good as is the case when a chief is believed to bring rain after a period of severe drought or bad as when a medicine man might inflict pain in a patient who promised to pay consultation or treatment fees. ${ }^{16}$

Beliefs in the supernatural powers of witch, the sorcerer, the medicine man (babalawo), or healer, diviners and the fortune tellers are widespread and strong among Nigerians and other Africans in general, the practices are hardly abandoned totally even among the devout Christian or Muslim converts. This reality gave reasons for the doubt of total conversion of Africans by early missionaries. For instance, it is not uncommon to find a Catholic Church member who received the communion at the 7 o'clock mass on Sunday and then return home to pour libations to the spirits or gods of his ancestors. The cases equally abound where members of the so-called Pentecostal movements arrive from churches to go to the babalawos (medicine men) to receive portions for the progress in their trade or business. Allegations has been made that some Pentecostal preachers have received their powers for the miracles they perform from traditional priests. The same reason may be adduced for the 
retention of several African traditional practices/ beliefs among the transplanted African in diaspora-in the voodoo rituals and in the highly emotional black American Baptist and Pentecostal churches in the United states in which the State of "possession" by the spirit among the worshippers might be linked to that of Africans in their worship/religious patterns.

This development of mixing religion by professing members of Islam and Christianity has led to the calculation that traditional religion marshals more followers than the foreign religions. However, the absence of a proselytizing spirit and the eternal tolerance for other religions on the part of traditionalist (who for example have never gone to war to stop foreign crusaders or to impose their beliefs on others) and the fact that education has meant westernization and concomitant abandonment of essential traditional tenet, which has put the future of traditional religion in Nigeria at risk. Traditional religion has never been a religion of divisiveness as compared to the rivalry between Christians and Islam which has led to conflicts and wars in Nigeria such as the bokoharam sect whose activities are directed against the western ideas of Christianity. This rivalry has led to riots and military coups in other parts of Africa such as Sudan, Chad and Kenya. ${ }^{17}$

Thus in the light of the aforesaid, it may be asserted that the pervasive religious outlook is one reason for the efficacy of the socio-political institution of the traditional societies, since the rules for all situations had been made by the ancestors and sanctioned by the gods of the lands, refusal on the part of anyone to conform was an affront to the spiritual components of the traditional societies believed to be capable of a long reach, the spiritual forces were certain to take retaliatory actions against those guilty of antisocial conduct. It was never too quick to enforce compliance with societal rules, conventions and even negotiations. It is interesting to note as part of the mechanism for policy making and policy execution in the traditional societies that oracles and diviners intervened in difficult cases which the living could not unravel and these cases were passed on to the supposedly omniscient ancestor and gods through the agency of the oracles.

The kings or the council of elders too had a role to play in the traditional scheme of life and events. They were to lead out in traditional ceremonies or sacrifices to the gods and sought the consent of their subjects as they could equally be sanctioned for abuse of power or office. That was the traditional setting which remained a working machinery for peace, tranquility, ensuring political economic and socio-cultural dimension of the peoples life before the arrival of the Europeans as Christians or as colonial agents in the African societies.

\section{Impact of Christianity and Colonialism on African Religion, Cultures and Ways of Life}

It is incumbent to further this discussion with the missionary factor as they were the fore -bearers of the colonial forces that emerged to the scene to invade, degrade and enforce Africans to the European cultures. It could therefore be asserted that Christianity came to black Africa before modern European colonialism to explore and prepare the ground for it. It must also be noted that European trade which had earlier been preceded by the slave trade, all had some attachment to Christianity. However as Ajayi has noted, while Christianity preceded colonialism in time, it had then only a small feeble presence with hardly any appreciable effects on the lives of the natives. It therefore can be said that it was the establishment of colonialism that boosted Christianity. ${ }^{18}$

The role of Christianity in the civilizing of black Africa is a matter of disputation among Africans. ${ }^{19}$ But as Prof Ben Nwabueze has rightly noted, "the dispute is not about whether Christianity in itself is good or bad. ${ }^{20}$ All seem to be agreed that there is much (not everything of course) that is good and worthy of emulation in life principles and values of Christianity. Such, for instance, is the Christian ethic of peace, order and justice, of the universal brotherhood of men and the basic equality of all men as being endowed by nature with its common humanity, respect for the dignity of the human person self-discipline, obedience, piety, love, tolerance, kindliness, humanness, mercy, tenderness, purity and chastity. Nor can it be denied that these principles and values, if faithfully applied would be a beneficial influence in instilling a greater moral sense and social stability in the peoples of Nigeria and Africa as a whole. Christianity has therefore played a distinctly/ civilizing role in Africa in stopping obnoxious practices like human sacrifice, slave dealing, the killing and disposing of twins, sorcery, witchcraft, trial by ordeal, and more importantly in spreading education and literacy by building schools, printing and publishing books, translating the bible into African languages, initiating the study of African languages and in improving health by building health centers, hospitals, maternities, modern transport, communications etc. Despite all these good points, however as Frantz Fanon has shown, "Christianity made itself a willing and ready tool in the hands of European colonialism to wage war on the embryonic heresies and instincts, and on evil as yet unborn" just as one used DDT to destroy parasites, the bearers of disease. ${ }^{21}$

The European Christian missionaries simply failed to appreciate the nature of the African pagan religion as something transcending more personal beliefs and forms of worship, as a whole social system encompassing the entire life and culture of the people, they saw in it no more than fetishes, idolatry and juju. The major instrumentality employed by missionaries was education. Through the medium of church education, Christianity was able to inculcate in the minds of children of Africa, a disdain for Africans pagan culture, but had also induced many of them to secede from it and renounce all its ways, even those with no religious associations of any kind like African dances, masquerades, wealth, tittle societies which were considered not in tune with 
European ways. It has however been advocated that for Christianity to thrive properly in Africa, it must undergo an indigenization process which initially had been started by process of decolonization which eventually led to independence of African states.

\section{Colonialism}

Colonialism has been defined as a forceful acquisition or absorption of a nation's sovereignty and independence by a foreign power. Thus despite the differences in the policies of the European colonial governments, French, English, Belgium or Portuguese, their basic goal appeared to be the same essentially: the political domination and economic exploitation of Africans. As Falola and Heaton has noted "the purpose of colonial rule was theoretically to alter only those customs, traditions and institutions that the British deemed harmful to the Nigeria's progress leaving existing political and social institution in fact to the greatest degree possible." In practice, however, colonial policies in southern Nigeria brought transformative changes to Nigeria societies in many ways, in both political and economic orientation.

Colonialism led to the emergence of a new class of European- educated, literate English speaking Africans, keen on holding the colonial regime responsible for its action and demanding for a greater role for them in their own governance - nationalism.

The colonial economic model also focused on expanding Nigeria's import- export market through increased cash crop and mineral production. The growth of cash crops like cocoa, coffee, groundnut etc., took over from the traditional mode of agricultural life of the people. This was done to redirect their markets to exports that would favour British. Also according to many African feminist, colonialism and the advert of foreign religious like Christianity and Islam (rather than African culture) are the factors that led to the social and economic relegation of African women to a lower status. ${ }^{22}$ As far as precolonial African economies were concerned, women played a very important role, but with the coming of the whites, women were made to play a second fiddle role to their husbands and relegate their functions. Also, the coming of the two religions Islam and Christianity has led to strife's and violence upon the polity in the years after the European left the country for example, between 1999 and 2004, no fewer than 100 conflicts were recorded in Nigeria due to religious conflicts between the two sects. This resulted in the death of at least 10,000 people and the displacement of about 800,000 people. It has encouraged interethnic killings especially between the Muslim north and the Christian in Nigeria.

The major examples of ethno-religious conflicts in Nigeria have included the Kafanchan-Kaduna crisis in 1987 and 1999, Zangon- kataf riots of 1992, Tafawa Balewa Clashes in 1991, 1995,2000, the Kaduna Sharia Riots of 2000 and the Jos Riots of 2001. All claimed several hundreds of lives and generated violent ripple effects beyond Kaduna, Jos respectively ${ }^{23}$

\section{Islam and its Impact on African Traditional Religion.}

Further, Azevedo highlighted on these factors observing that in contrast to the European missionaries' intolerant and hostile attitude towards Africans, their religion and culture generally, the Islamic religion in Nigeria as well as other Africans was accompanied with forbearance, sympathy and respect for native customs and prejudices. The progress of Islam and its spread in Africa has been attributed in part to the fact that it did not denigrate Africans as inferior caste nor seek to destroy their cultures completely as unworthy of existing alongside itself. The Islamic faith accompanied its spread with traders who were genuine and aligned with Africans in fraternization of their faith. They established themselves in kings palaces became palace administrators, through the Arabic languages which soon became the courts in keeping and administration. The commercial links with North Africa through trade routes from Nigeria to Fez, Morocco, Tunisia, Chad, and Egypt linked Nigerian traders to North Africa and even Europe where goods flowed across the Mediterranean Sea.

This contrasted to the initial approach of the spread of Christianity. Apart from their intolerance in African institutions, Christianity favored individuals, personal quest for salvation whereas indigenous African traditional religion favored a communal approach. It was this misunderstanding which gave the Islamic faith an edge in proselytization of their religion in Africa.

As was explained in Bosworth Smith's highly acclaimed book, Mohammed and Mohammedanism (1876), part of the reason why Christianity after more than 500 years since its advent in black Africa in 1481, has established itself as Islam has done as the religion of any of the African communities, apart from individual converts who no doubt are numbered in millions is because the Arabs receive their converts on terms of entire social equality while Europeans, in spite of the efforts to the contrary, seem either unwilling or unable to treat their converts as other than inferiors. And while Christianity endorsed slavery, a slave or even an outcast, once converted to Islam becomes free and was accorded equality with his former master and with the proudest noble man it is this tolerant and accommodating attitude of Islam which allowed it gain more converts in the early days of proselytization. ${ }^{24}$ 


\section{Impact of Christianity on African Traditional Religions}

No doubt Christianity has led to fundamental shifts in African societies. Missionaries preach against slave trade and slavery, human sacrifices, twin destruction, institution of polygamy, title taking and secret societies. Education was made the indispensable hand maid of evangelism wherever they settled they established schools. In the linguistic view, their work is laudable, they reduced to many African languages the works of Rev. S.W. Koelle who produced a grammar of Bornu or Kanuri language; and African Narrative literature in Kanuri. ${ }^{25}$ J.F. Scholar who published a Hausa primer and grammar of Hausa language. Hope Waddel and Rev. Huge Goldie pioneered works in Efik languages. Through their efforts, they initiated the scientific and systematic study of African languages.

In 1852, Rev.Townsend brought the first printing press into Nigeria and established the first newspaper in west in the Yoruba language, The Iwe Iroyin in 1859. The emergence of West African elite a new class of African educated not only in European literacy skills and technology but also in ways of thought. This class played a prominent role in the economic, social and political industry of Nigeria, they served the missionaries, colonial governments and European firms as priests, teachers, administrators and professionals. European medical services, hospitals, manufacturers and history of medical services in Nigeria began with arrival of Rev Father Coquard in Abeokuta in 1890.

Some of the acts of early missionaries had to do with the condemnation of indigenous African names, art, fables and even dress patterns. Polygamy was out rightly condemned not minding the benefits and implication of large families to the farming/agricultural pursuits of the people at that level of division of labour. Some missionaries went so far as setting the mission house above the authority of the traditional rulers. ${ }^{26}$ Also African indigenous music and dances, however unconnected with juju and idols were relegated as fetish. It is also important to observe that it was the denigration of the African early church leaders as inferior that led to the breakaway and the formation of the first independent African churches between 1884 and 1911, which developed into the Ethiopian and Millenarian/ Pentecostal churches. According to Adu Boahen, Ethiopian type emphasized African self -improvement, self-rule, political rights. The Pentecostal type emphasized spirit possession, healing by faith and prophecy: these churches have since proliferated to an almost incredible extent as regards both members of adherents and sects. Obviously, the indigenous of the Christian churches has continued to progress as concerned its personnel and composition of ethics and values.

Perhaps, it is pertinent to resort to historical antecedents in order to justify the paganism of Africans which is not exempt from other cultures and societies of the world. Paganism in Europe could not be out rightly suppressed by early Christian churches. Realizing that ancient rites and customs that had governed the life of people for centuries could not be suppressed outright without a resultant social chaos. Confusion and instability, the early Christian quite wisely condoned or accepted practices and later transformed them. For example an intimate and trustful worship of saints replaced the cult of the pagan gods and satisfied the congenial polytheism of simple or poetic minds. ${ }^{27}$

The Christian calendar of the saints replaced the roman fasti; ancient divinities in Europe close to the heart of the heart of the people were allowed to revive under the names of Christian saints- the Dea Victoria of the Bases Alpes became st. Victoire, and castor pollus were reborn as Sts Cosmas and Damain. As Prof. Nwabueze has noted "this tolerant of adaptation was perhaps best exemplified in the sublimation of the pagan mothergoddess cults in the worship of Mary. Gradually, the tenderest features of Asarte, Cybele,Artemis, Diana and Isis all of Greek and Roman gods and goddesses were gathered together in the worship of Mary."28

In the sixth century, the Christian church established the feast of Assumption of the Virgin into heaven and assigned it to August 13, the date of ancient festival of Isis and Artemis. Also ststus od Isis and Horns were renamed Mary and Jesus; the Roman Lupercalia and the feast of the purification of Isis became feast of nativity; the saturnalia were replaced by Christmas clebrations, the Floralia by Pentecost, also an festival of the dead was replaced by All Souls Day, while the resurrection of the Attis was replaced by the resurrection of Christ. Even pagan Temple were reconstructed for Christian use, the pantheon dedicated to Virgin Mary and all Martyrs (609AD), the temple of Jamis became the church of St. Dionysius while the temple of Saturn became the church of the savior.

Also notable is Pope Gregory's indulgence towards the lingering paganism in England (601AD) when he permitted the custom of sacrificing oxen to the gods to be gently transformed into killing them to the refreshing of themselves to the praise of God. The use of vest, incense and holy water in purification, burning of candles and everlasting light before the alter, the architecture of Basilica, the tittle of Pontifex Maximus for the supreme Pontif are all ending vehicles of catholic ritual reminiscent of paganism.

As Ajayi has posited, foreign religion therefore cannot claim to be entirely from paganism indulgence. The claim by Christians that pagan culture was synonymous with barbarism is not true. This is because the great civilization of antiquity, Cretan, Greek, Roman and others developed and followed under paganism as the religion of the state. The Cretans worshiped mountains, Caves, Stones, Number 3, tress and pillars, sun, moon, goats and snakes, doves and bulls, hardly anything he adds escaped his theology. 
Greek, the mother of European civilization and the rod spring of nearly everything secular in our modern culture (except machinery)- school, sports, Arithmetic, geometry, physics, Biology, anatomy, Hygiene, Therapy; Medicine, Poetry, Art, Music, Drama, Philosophy, Politics, Democracy etc. - grew and thrived within the framework of paganism as state religion.

Just like the African, every family in Greece had its own god to whom divine fire burned un-extinguished at the heath offerings of food and wine were made before every meal. The similarities to Africa's paganism culture is most striking indeed. The sacrifice of human beings to the gods continued until the second century AD and animal sacrifices was stopped much later by Christianity.

As Prof. Ben Nwabueze had rightly asserted, Africa is in good company with pagan culture and not to be degenerated because of its form of worship to the gods or goddesses since renaissance, all belonged to a period of their lives. ${ }^{29}$ Thus Justus Okah-Avae has rightly noted, "Every society is a delicate organization of different and often conflicting human interests, aspirations and perspectives of world" any inspired knowledge is claimed to be a directive from God, so that it would be feared, revered and obeyed. Also, he noted that a careful study and analysis of all religions across the globe and across all ages and cultures, may not be the same but the facts are similar. There the principle of one boundless immutable, absolute reality- that of a supreme being-logos (God, Olodumare, Chukwu, Obangiji) this reflected in all religions- Christianity Islam, African traditional religion, Buddhism and Confucianism. ${ }^{30}$

Okah-Avae further asserts that the mistaken belief by Christians that Jesus was the only son of God, born of Virgin Mary is replicated in other religions of the world. All of them have the following broad characteristics; born in a cave about the time the sun is starting its journey to the south, and by a Virgin whose name has the same meaning or connotation as Mary. Secondly, they all went into oblivion and re-emerged about the age of 30 and had a short ministry just like Jesus. Thirdly, they were arrested, falsely accused, crucified and died on the cross at the full moon of Aries. (However, in other cases, the four-arm cross, not the Christian Cross was represented.) And finally, all of these Characters rose from the dead after three days and thereafter ascended to heaven. ${ }^{31}$

For example the Egyptian records show that Horous was born of the Virgin Isis, Queen of Heaven, "mother of God" in fact, at the time Joseph was sold to Egypt by his hostile brothers, Isis-some meaning of Mary was already revered in Egypt. ${ }^{32}$

\section{Conclusion \\ Upgrading African Culture}

The position of this paper once again comes to the reference of African culture as tolerative of its customs, practices and obligations which has been highly under the African traditional religion. The argument of the work is that African traditions are African, while the Christian faith of the Judeo-Greek-roman-western culture and Islam of the Arabian background have their own traditional basis as well, therefore none of them should be degraded ahead of the other. The work has highlighted the derivable advantages from the foreign and indigenous religions. It is therefore important to reconcile that African past must not be sacrificed on the altar of the foreign religions, -Islam and Christianity, rather, as the Islamic faith had done in earlier years, Christian leaders who are now Africans should find a way of reconciling true African cultural values as distinct from religious dogmas. This process of cultural renaissance should seek to lift African cultures from their degraded status to a position of equality of rights and dignity with the culture of other races to rekindle loyalty to, and interest pride in them to restore them to the rejuvenated place in the lives of African educated classes. ${ }^{33}$

The expected cultural renaissance being advocated for should mean a return with a renewed loyalty and pride to Africans cultural heritage which of course should be shorn of any of its former obnoxious practices or undesirable aspects which to all intents cannot be tolerated by modernism, cultural renaissance must therefore seek to rouse in Africans, Nigeria's sense of pride in the dignity, loyalty, glory and solemnity of a civilization and culture which it is affirmed has been discovered by contemporary scholars to have existed in Africa in some of its empires, states and societies.

It must be accepted and asserted that traditionalism is indigenous to Africa, and contrary to myths and stereo-types, perpetuated by European traders, explorers, missionaries, early ethnographers, ATR enshrines the essential elements of any other religion of the world, namely the belief in the creator, in spirits, the recourse to sacrifice, prayer and the use of rituals. The veneration and invocation of the ancestors could be compared to the prayers, addressed to saints among some Christian denominations.

Finally, a strong appeal is hereby advocated by this work for tolerance among these three major religions. Christians and Islamists should not see practitioners of African traditional religion as inferior or timid, rather each must tolerate the values and ideas of one another. Fortunately, there seems to be a steady but slow shift by the entire human family towards unification of religious ideas and with that the spell of fear surrounding the entire collapse leading to virtual independence of all religion of the world. ${ }^{34}$ From Asia are the records of Dawaki, the virgin mother of Krishna. And from Babylon, comes Mylitts or Istar, Virgin mother of Tammus, 
Mecury Aesulpius, Bacchus, Hercules, Mitrus and Zaratrusta, all of the Greek, Roman and Persian mythology were Virgin births. In China too, Mayadevi was the Virgin mother of the Lord Buddah. Similar records are also found in the ancient records of Mexico and South America.

Therefore, as Okah-Avae further noted, it is a grievous error for Christians to think that the God they worship is the True god or Universal God, while the god of others is tribal and primitive. The God that Christians propagate is the tribal god of Israel which is quite different from the tribal god of Syria, Assyria, Philistines, Greek, Romans, Yorubas, Igbos, Binis, and others. The neutrality of God is of universal application.

\section{REFERENCES}

${ }^{1}$ Justus Okah-Avae; "Religions and Spiritual State of Man : Emergent Realities and Developments of Religious State of Man in the African World" in Studies in the African Human Culture and Development, Issues in the post-Colonial Era FBO A Akporoba et;al, Princeton and Associates, Lagos 2015, 52.

2 JFA. Ajayi; Christian Missions (1965) 4.

${ }^{3}$ E.A. Ayandele, The missionary Impact on Modern Nigeria 1842-1914, 6.

${ }^{4}$ Justus Okah Arae 53.

${ }^{5}$ Ben Nwabueze; Cultures and Ways of Life in Colonialism in Africa: Ancient and Modern Vol2.Gold Press 2010.

${ }^{6}$ Edward Blyden, Christianity, Islam and the Negro Race (1887) reprinted in 1967 P11-12 as Cited by Ben Nwabueze above.

${ }^{7}$ Igwe,U.A. and Adeyemi, B, concept of Culture and Early Cultural Centres in Adewoye Ominiyi "SocioPolitical Institutions in Traditional Nigerian Societies" in Nigerian Peoples and Culture, Babatunde Adeyemi, (Babcock University Press, 2011), 2014, p 17

${ }^{8}$ Okah-Avae 53.

${ }^{9}$ Edward Geoffrey Parrinder, Religions in Africa, Baltimore, Penguin Books, 1969,p 400-407

${ }^{10}$ Mario Azevedo, Religion in Africa in Africana Studies; A Survey of Africa and the African

Diaspora ed. Mario Azevedo Carolina Academic Press Dunham, North Carolina, p. 391-401

${ }^{11}$ Ibid

${ }^{12}$ John Mbiti : African philosophies and religions, London: Heinemann, 1969.

${ }^{13}$ Adewoye Omoniyi, "Socio-Political Institutions in Traditional Nigerian Societies" in Nigerian Peoples and Culture, Babatunde Adeyemi, (Babcock University Press, 2011), 2014, P29-38

14 Adewoye Ibid.

15 Adewoye Ibid.

${ }^{16}$ Mario Azevedo Religion in Africa in Africana Studies; A Survey of Africa and the African

Diaspora ed. Mario Azevedo Carolina Academic Press Dunham, North Carolina, p. 391-401

${ }^{17}$ Ibid.

18 J.F.A. Ajayi -Christians' in Nigeria (1965) pg. 123.

${ }^{19}$ Popoola M.A, British Conquest, Colonialism and its Impact in B.Adeyemi, Nigeria People and Culture P62.

${ }^{20}$ Oluwole Omoni- Colonial Policies and Independence Movements in Richard Olanyan, Africa History and Culture, lagos, Longman Nigeria 1982, P81.

${ }^{21}$ Franz Fanon, The Wretched of the Earth P34

${ }^{22}$ Robert Dibbie and Christianah Atibil non-governmental organization(NGOS) and the social and Economic Empowerment of Women in Ghana and Nigeria, Journal of international politics and development Vol 10, N0s 1 and 2, June, 2012, Lagos Emaphine reproduction, p 27-61.

${ }^{23}$ Osahe and subsu 2005 as quoted by Tomomewo Amos etal; The Emergence of Christianity and Islam and its Impact on Nigerian People and Culture, Unpublished article 2013 p.7-11 submitted in partial fulfilment of GEDS 134.

${ }^{24}$ Blyden as cited by Azevedo, Religion in Africa in Africana Studies

${ }^{25}$ G.I.C. Eluwa and M.O. Ukaegbu etal; Africa and the Wider World Since 180AD, Onitsha, Africana fep Publishers Ltd. 1996,p 56

${ }^{2626}$ A.Adu Boahen, Africa : colonialism and independence in Africa Today, ed Ralph uwechue()1991. P 178 as cited by Prof.Ben Nwabueze.

${ }^{27}$ Will Durant: the Story of Civilization, W p183

${ }^{28}$ Ibid.

${ }^{29}$ Nwabueze as cited in Ofor, Acient and Mordern Degradation of Africans Pagan Religion, Cultures and Ways of Life

${ }^{30}$ Justus Okah-Avae, Religions and Spiritual State of Man: Emergent Realities and Developments of Religious State of Man in the Studies in the African Human Condition, p66.

${ }^{31}$ Ibid. 


\footnotetext{
32 Ibid.

${ }^{33}$ John Mbiti : African philosophies and religions, London: Heinemann,1969.

${ }^{34}$ Avae- Okah P75.
}

Further readings

1. Walter Rodney; How Europe Underdeveloped Africa, Dares Salmi, Tanzania Publishing House, 1972.

2. Basil Davidson; the African Genius Boston: Little Brown.

3. Philip Curtin, et al, African History.

4. Ira M. Lapidus; A history of Islamic Societies Cambridge: Cambridge University Press, 1970.

5. P.M. Holt et al; (eds), the Cambridge History of Islam vol. 2, Cambridge University, 1970.

6. C.G Baeta, Christianity in Tropical Africa, Oxford: Oxford University Press, 1968.

7. C.C Sterat Islam in J,D,Fage and Roland Oliver(eds) The Cambridge History of Africa 1905-1940, Cambridge, Cambridge University Press, 1986.

8. Sulayman Nyang: Islam Christianity and African Identity, BattleBoro: Amana Book Publishers 1984.

9. David Westerbind: African Religion in African Scholarship, a Preliminary Study of the Religious and Political Background, Stockholm Almqvist and Wiksell International, 1985.

10. Franz Fanon, The Wretched of the Earth. P. 34 